\title{
Supporting Students with or at Risk of Emotional Disturbance within the Response to Intervention Model: A Systematic Review
}

\author{
Areej Alsalamah \\ Department of Special Education, King Saud University, Riyadh, Saudi Arabia \\ ORCID iD: https://orcid.org/0000-0003-3059-3700
}

This research was not supported by any grants.

\section{Abstract}

The response to intervention (RtI) model is a pre-referral model adopted by schools in the United States to prevent academic failure and enhance students' academic outcomes. Recent research in the educational field suggests that integrating behavioral components into this model can support students with or at risk of emotional disturbance (ED). This study provides a systematic review of studies published between January 2004 and April 2020 that employ experimental research designs to examine the implementation of RtI to support students with or at risk of ED. A total of seven studies were identified and reviewed. Results vary for the implementation of RtI to support students with or at risk of ED. Although some studies reported potential positive effects of implementing RtI to reduce disruptive behaviors among students, other studies reported that students were unresponsive to the received behavioral intervention within RtI. Further studies are thus needed to fill the gap in the literature on how students with or at risk of ED can be supported by schools adopting the RtI model.

Keywords: Response to intervention, Emotional disturbance, Emotional and behavioral disorders, Behavioral challenges, Emotional challenges

DOI: $10.7176 / \mathrm{JEP} / 11-36-08$

Publication date: December $31^{\text {st }} 2020$

\section{Introduction}

Working with students with or at risk of emotional disturbance (ED) is considered one of the greatest challenges confronted by educators (Gresham, 2015). These students exhibit a plethora of problems, such as lack of engagement with school and learning, poor school attendance, difficulties in developing and maintaining appropriate relationships with their teachers and peers, lack of academic achievement, low rate of graduation and employment, and high risk of drug use, imprisoned, and suicide (Lewis, Mitchell, Bruntmeyer \& Sugai, 2016). Because most of these students are too aggressive, they often experience social rejection (Kauffman \& Landrum, 2018). Finally, when compared with students belonging to other disability categories, these students also represent the highest percentage of students $(35 \%)$ who dropped out of school (National Center for Education Statistics, 2019).

ED is defined under the Individuals with Disabilities Education Act (IDEA, 2004) as follows:

(i) Emotional disturbance means a condition exhibiting one or more of the following characteristics over a long period of time and to a marked degree that adversely affects a child's educational performance:

(A) An inability to learn that cannot be explained by intellectual, sensory, or health factors.

(B) An inability to build or maintain satisfactory interpersonal relationships with peers and teachers.

(C) Inappropriate types of behavior or feelings under normal circumstances.

(D) A general pervasive mood of unhappiness or depression.

(E) A tendency to develop physical symptoms or fears associated with personal or school problems.

(ii) Emotional disturbance includes schizophrenia. The term does not apply to children who are socially maladjusted, unless it is determined that they have an emotional disturbance under paragraph (c)(4)(i) of section 300.8 .

National Center for Education Statistics (2019) published a recent survey of crime, violence, discipline, and safety in US public schools between 2017 and 2018, and it found that $71 \%$ of US public schools reported a total of 962,300 violent incidents, and $21 \%$ of those schools reported serious violent incidents (Diliberti, Jackson, Correa \& Padgett, 2019). According to the latest report on the estimated numbers of students with disabilities in US, students with ED accounted for 5\% of students who served under IDEA (2004) in the 2016-2017 school year (National Center for Education Statistics, 2019). Students with or at risk of ED usually experience long-term behavioral and academic struggles without receiving appropriate services (Kauffman \& Landrum, 2018). This highlights the importance of adapting prevention and intervention models to address the behavioral and academic challenges among students with or at risk of ED.

Many schools in the US indeed have been implementing tiered-support models such as positive behavioral intervention and supports (PBIS) to provide behavioral prevention and intervention or multitiered systems of support (MTSS) to provide academic and behavioral prevention and intervention for all students including those who exhibit behavioral challenges behavioral challenges (Lane, Oakes, Buckman \& Menzies, 2019). Although 
these models have been frequently discussed in the literature as prereferral models that are used to provide behavioral support, some researchers suggest using other tiered-support models that were developed to provide academic support such as response to intervention (RtI) for similar purpose too (Malecki \& Demaray, 2007). Recently, a few studies have been published to discuss the possibilities of using the RtI model to provide behavioral prevention and intervention to support students with or at risk of ED (McIntosh, Campbell, Carter \& Rossetto Dickey, 2009; Sinclair, Gesel \& Lemons, 2019; Szwed \& Bouck, 2013).

\subsection{Addressing Behavioral Challenges within the RtI Model}

The reauthorization of IDEA (2004) has helped improve the educational and behavioral practices provided to students with or at risk of ED. According to IDEA (2004), students with ED have the right to receive appropriate education in a less restrictive environment (Office of Special Education and Rehabilitative Services, 2016). In addition, schools are required to provide students with evidence-based interventions and support to prevent and address behavioral and educational challenges (Sugai \& Horner, 2009). In light of the IDEA legislation, schools can now use a student's response to evidence-based interventions and support as a method for determining whether the student is eligible for special education services (Hosp, Huddle, Ford \& Hensley, 2016).

Since the IDEA reauthorization in 2004, many schools have started adopting a multi-tier system of support, such as RtI, to employ effective evidence-based interventions and assessment practices in less restrictive environment and to promote positive academic outcomes for all students (Jimerson, Burns \& VanDerHeyden, 2016). According to the National Center for Education Evaluation and Regional Assistance (Bradley et al., 2011), RtI implementation has increased significantly, with $71 \%$ of 1,148 districts reported to have applied RtI in their schools in the 2008-2009 school year (Bradley et al., 2011). Although the RtI model has focused primarily on academics, $36 \%$ of districts reported implementing behavioral aspects in their RtI model at their schools. Some districts reported adapting an RtI model that combines behavioral and academic aspects, and $28 \%$ of districts indicated implementing this combination in elementary schools, $33 \%$ in middle schools, and $31 \%$ in high schools (Bradley et al., 2011).

Recent research in the behavioral field has discussed the advantages of integrating academic and behavioral components in the RtI model (Gresham, 2007) and how the RtI model can address both academic and behavioral challenges for all students, including those with or at risk of ED (Brown-Chidsey \& Steege, 2010). Gresham (2007) suggested that including behavioral and academic components in the RtI model can help schools identify students with ED sooner and provide appropriate early-stage interventions. An RtI model that includes behavioral and academic components can also encourage schools to focus on students' outcomes; the model interprets behavioral problems from an at-risk perspective rather than from a deficit model perspective, and this shift of focus can help reduce the number referrals to special education, especially for students who belong to minority groups. Some researchers emphasized the importance of integrating behavioral and academic components into the RtI model because they found a connection between academic and behavioral outcomes and showed that providing intervention in one of them can enhance outcomes and prevent failure in the other area (Nelson, Benner, Lane \& Smith, 2004).

Many studies highlighted the relationship between academic and behavioral aspects. For example, Gage, MacSuga-Gage, Prykanowski, Coyne, and Scott (2015) investigated how early literacy skills among students who are at risk of developing reading difficulties can be affected by evidence-based behavioral management interventions. Their results showed that students' literacy skills can be influenced positively when students receive high-quality evidence-based behavioral management strategies, such as prizing specific behaviors and providing clear behavioral expectations and opportunities to respond. Gage et al. (2015) also emphasized that a highly qualified behavioral manager should provide these behavioral interventions within instructional contexts.

The relationship between behavioral and academic outcomes was also confirmed by Nelson, Benner, and Gonzalez (2003) after conducting a meta-analysis of 30 studies to identify which characteristics can affect students' performance in early literacy skills. The results identified behavioral problems as a factor that can impact students' academic outcomes. Al Otaiba and Fuchs (2002) confirmed that having attention or behavioral challenges can prevent students from benefiting from academic intervention. Therefore, integrating academic and behavioral intervention within the RtI model not only improves students' outcomes, but also facilitates the inclusion of students with or at risk of ED in general educational settings (Stoutjesdijk, Scholte \& Swaab, 2012).

The RtI model contains multiple components to help schools enhance their climate and safety and improve both behavioral and academic outcomes among all students (Gresham, 2007; Malecki \& Demaray, 2007; Office of Special Education and Rehabilitative Services, 2016; Sugai \& Horner, 2009). These components include (a) employing multiple tiers of prevention and intervention, (b) implementing evidence-based practices for intervention and measuring, (c) using universal screening to identify students who are at risk of behavioral or academic challenges, and (d) monitoring students' progress to decide the appropriateness of the intervention (Greenwood, Kratochwill \& Clements, 2008). Within the multiple tiers of RtI, schools can increase the intensity of intervention so as to meet their students' needs (Saeki et al., 2011), and this may help address the number of 
students who are at risk of ED and/or academic failure (Lewis et al., 2016; Saeki et al., 2011).

In Tier I of the academic and behavioral RtI model, schools provide all students with clear behavioral expectations and instructions (Office of Special Education and Rehabilitative Services, 2016). Teachers in this tier explicitly describe acceptable behaviors, and they then reward students who adhere to the behavioral instructions and clarify the consequences of violating the behavioral roles (Grosche \& Volpe, 2013). Based on how students respond to Tier I, the school may identify students who are unresponsive to Tier I instruction; these students will then be targeted by Tier II intervention. When schools provide students with more intensive behavioral instruction within small groups, these instructions may include procedures such as implementing check-in/check-out (CICO) (Bruhn, Lane \& Hirsch, 2014), reteaching basic academic and social skills, and providing additional chances for practice and feedback (McIntosh, Goodman \& Bohanon, 2010). Students who continue to struggle in Tier II are eligible for Tier III intervention, which is designed to provide extra-extensive intervention to target each student's distinct needs (McIntosh, Bohanon \& Goodman, 2010). In Tier III, schools provide students with individual behavioral plans that are based on functional behavioral assessment (Hawken, Vincent \& Schumann, 2008). Students in this tier may receive mental health services outside their schools, in which case schools are required to conduct a wraparound meeting to a comprehensive individual intervention plan that unifies the efforts of educators, parents, and specialists to achieve the target goals in different settings, including the school, home, and society (Karam \& Wright, 2015).

Within the multiple tiers of the behavioral and academic RtI model, general education teachers collect data about students' academic and behavioral performance that reflect the function of the behavior and illustrate the interaction of academic and behavioral performance (Brown-Chidsey \& Steege, 2010). Educators use this data to determine the current level of students and to select the most appropriate evidence-based intervention for students' behavioral and academic needs to ensure the integrity of the intervention (Algozzine, Putnam \& Horner, 2012; Gresham, Hunter, Corwin \& Fischer, 2013). As Lewis et al. (2016) noted, the supports provided by RtI tiers exceed developing academic and behavioral outcomes among students to enhance job satisfaction across educators.

However, although researchers recommend the RtI model because it can be adapted by schools to support students with or at risk of ED (Hawken et al., 2008; Sugai \& Horner, 2009), most of the published research studied only the academic aspects of RtI and how RtI can be used to identify learning disabilities (Hawken et al., 2008). In the published research to date, there has been no systematic review that focuses exclusively on RtI implementation to support students with or at risk of ED (Sugai \& Horner, 2009). Therefore, the primary purpose of the current systematic review is to answer the following research questions about studies that examine the implementation of RtI for students with or at risk of ED: (a) What are the key characteristics of students and settings that were included in studies about implementing RtI (e.g., gender, grades, disabilities; general/special education classroom, playground, lunchroom)? (b) Which experimental research designs (e.g., single-subject, experimental, quasi-experimental) were employed these studies? (c) What independent and dependent variables do these studies use? (d) What tools do researchers use to screen and monitor students' behavior within the RtI tiers? (e) What are the outcomes of these studies?

\section{Method}

\subsection{Study Identification Process}

The present systematic review aimed to identify how the RtI model has been implemented to support students with or at risk of ED. A systematic review was preferred to a meta-analysis because the studies included lacked information about one or more essential details (e.g., study design, standard deviation, group means, correlation between pre- and post-measurement) (Liberati et al., 2009). A two-phase procedure was followed to find potential articles: (1) Searching widely used databases in educational and behavioral sciences, including Google Scholar, EBSCO, ERIC, ProQuest, and SAGE. During this search, the following four keywords were used: "response to intervention and emotional disturbance," "response to intervention and EBD," "response to intervention and behavioral challenges," and "RtI and behavioral support." These keywords were selected because they are often used in the RtI and behavioral literature. (2) Checking the reference lists of identified articles to determine whether any further published research could be included. These two research phases produced 514 articles.

\subsection{Criteria for Inclusion and Exclusion of Studies}

Inclusion and exclusion criteria were checked for 62 of the 514 articles found through the study identification process. The inclusion criteria aimed to find studies that focused on the implementation of RtI to identify and/or support students with or at risk of ED. These studies had to use experimental research designs such as singlesubject, experimental, and quasi-experimental. These designs are recommended by the Council for Exceptional Children (CEC) (Odom et al., 2005) and the What Works Clearinghouse (WWC, 2019) because they encourage evidence-based educational practices by clarifying whether a specific practice can make desirable changes in students' outcomes in a specific area among the target population. The selected studies also had to be conducted in the United States and be published in English in a peer-reviewed journal between January 2004 and April 2020. 
The exclusion criteria excluded studies that discussed the implementation of RtI to support students with or at risk of disabilities other than ED and studies that examined multi-tier systems of support other than RtI. The exclusion criteria also excluded studies that did not employ experimental research designs (e.g., reports, narrative reviews, and qualitative designs), studies conducted in countries other than the United States, and studies published in a language other than English and not published in peer-reviewed journals. Articles published before 2004 were excluded because the implementation of RtI spread widely after the reauthorization of IDEA (2004) and Jimerson et al. (2016).

A total of seven studies met the selection criteria and were thus included in this systematic review. These studies were published in peer-reviewed journals that focused on discussing educational and/or behavioral practices and helping educators select appropriate interventions to enhance students' behavioral and educational outcomes. Researchers can also be guided through these journals to conduct further future research to identify and develop best practices appropriate for all students, including students with disabilities or at risk of being identified with disabilities. The journals include School Psychology Review, The Rural Educator, The Journal of Special Education, Exceptional Children, Journal of Special Education Technology, and Journal of Positive Behavior Interventions.

\subsection{Coding Procedures}

A content analysis was conducted for each study selected for final review. Coding was based on the following specific categories: (a) publication information (e.g., author, journal, year of publication), (b) study design (e.g., single-subject, experimental, and quasi-experimental), (c) participants (e.g., gender, age, grade level, disabilities), (d) school settings (e.g., general education classroom, special education classroom, playground, lunchroom), (e) independent variables applied within the RtI tiers, (f) dependent variables targeted by RtI tiers of intervention, (g) screening and assessment tools applied to screen students or monitor their progress, (h) significant results of the study, and (i) validity and reliability of the intervention. The researcher coded each category in every publication included in the review and noted important information. More information was added after conducting multiple reviews of each included study.

\section{Results}

\subsection{Characteristics of Students and Settings}

A total of 185 students with or at risk of ED were included in the seven studies used for this systematic review. See Table 1 for a summary of these studies. These studies included 41 female students $(22 \%)$ and 144 male students (78\%) from a range of ages and abilities. The students were 4 to 13 years old, and most of the students (93\%) were elementary school students; only two studies included kindergarten students (Barnett et al., 2006; Pearce, 2009), and one study included a middle school student (Sinclair et al., 2019). All students included in the studies displayed sustained patterns of behavioral problems: 35\% had disabilities, and 19\% of these disabilities were related to learning disabilities (Cheney, Flower \& Templeton, 2008; Fairbanks, Sugai, Guardino \& Lathrop, 2007; Pearce, 2009; Szwed \& Bouck, 2013). In addition, $28 \%$ of students with disabilities were taking medication to control symptoms related to ED. However, the disability status of students was not reported in the two studies (McIntosh et al., 2009; Sinclair et al., 2019), and in three studies researchers did not state whether the students received medication for ED (Cheney et al., 2008; McIntosh et al., 2009; Sinclair et al., 2019).

In two studies, researchers reported excluding students who displayed behavioral challenges that did not fit the patterns of behavior exhibited by the included students, who constituted a homogeneous group. McIntosh et al. (2009) reported excluding six students from participation because they exhibited functions of behavior that did not fit the common behavioral functions displayed by most of the study's participants. In addition, Cheney et al. (2008) excluded students with poor attendance rates.

In four studies, researchers included students from different ethnic groups: African American $(n=28)$, American Indian or Alaskan Native $(n=6)$, Asian $(n=8)$, Caucasian $(n=86)$, European American $(n=30)$, Hispanic $(n=12)$, and Latino $(n=2)$ (Cheney et al., 2008; Fairbanks et al., 2007; McIntosh et al., 2009; Sinclair et al., 2019). Szwed and Bouck (2013) reported the ethnicity of the population in general without clarifying the ethnicity of the included sample. Two studies did not provide information about students' ethnicity (Barnett et al., 2006; Pearce, 2009).

The studies were conducted at public schools located in the following geographical regions: two studies in urban schools (Sinclair et al., 2019; Szwed \& Bouck, 2013), one in a suburban school (Fairbanks et al., 2007), and one in rural schools (Pearce, 2009). Three included studies did not indicate information about the geographical region of the schools (e.g., suburban, urban, or rural) (Barnett et al., 2006; Cheney et al., 2008; McIntosh et al., 2009). One study was applied in schools that included a Head Start program (Barnett et al., 2006); one study was applied at schools that used the Check, Connect, and Expect Project (CCE) (Cheney et al., 2008); and one study was conducted in a school that provided a high-ability program for talented and gifted students (Szwed \& Bouck, 2013). 
In six studies, students received the RtI intervention to improve their behavioral outcomes in a general education classroom setting (Barnett et al., 2006; Cheney et al., 2008; Fairbanks et al., 2007; McIntosh et al., 2009; Pearce, 2009; Szwed \& Bouck, 2013). In one study, students received the intervention in an intervention classroom (Sinclair et al., 2019), while in other studies they received intensive intervention in general and special education classroom settings (Pearce, 2009). In two studies, students' behaviors were monitored and supported within the RtI in different school settings beyond the general education classroom, such as the playground, lunchroom, or cafeteria (Barnett et al., 2006; Cheney et al., 2008).

\subsection{Design of the Studies}

All included studies employed causal research designs where the main independent variable was RtI intervention and the dependent variables were students' behavioral outcomes.

Four studies employed single-subject study designs, including withdrawal design (ABAB) (Sinclair et al., 2019; Szwed \& Bouck, 2013), multiple-treatment design (A-BCD-BC-B) (Barnett et al., 2006), and multiplebaseline design across participants, which was implied as a second study design in Fairbanks et al. (2007). Two studies used a quasi-experimental design (Fairbanks et al., 2007; McIntosh et al., 2009). Two studies did not mention the study design explicitly; however, one study included experimental and comparison groups, and schools were randomly assigned to include experimental or comparison conditions (Cheney et al., 2008). In the other study, the researcher applied the intervention to a group of students from two schools who displayed significant emotional and behavioral problems (Pearce, 2009).

In one study, researchers implemented the study in randomly assigned schools, dividing the schools into those with intervention conditions and those with comparison conditions (Cheney et al., 2008). However, students in this study were assigned to intervention groups depending on their teachers' rating of them in the Systematic Screening for Behavioral Disorders. Researchers in five studies selected students for their studies based on teachers' reports (Sinclair et al., 2019) or referrals (Barnett et al., 2006; Cheney et al., 2008; Fairbanks et al., 2007; McIntosh et al., 2009). Barnett et al. (2006) used the students' screening results, parent reports, and teacher referrals to select their study participants. In the second study, Fairbanks et al. (2007) identified students based on their unresponsiveness to Tier II of RtI behavioral intervention. Szwed and Bouck (2013) used purposive sampling to assign study participants according to specific criteria determined by the researchers (e.g., second-grade students, students with behavioral challenges, students receiving special education or RtI services). In one study, the researcher did not provide any information about how students were selected to participate (Pearce, 2009).

In four studies, the researchers reported using procedures to assess students' behavioral outcomes before and after conducting the studies. McIntosh et al. (2009) utilized teachers' ratings of the included students according to the Behavior Assessment System for Children, Second Edition (BASC-2). Cheney et al. (2008) used Systematic Screening for Behavioral Disorders to assess students before the study, and they used teacher ratings of students' behavior according to the behavioral expectation at the end of every intervention period. Fairbanks et al. (2007) developed rating scales for teachers to use before, during, and after the intervention to assess students' behavioral outcomes. Szwed and Bouck (2013) interviewed teachers before and after the intervention to learn about the intervention and students' behavioral outcomes. They also included a maintaining phase with three data points to assess students' behavioral outcomes after the intervention. Sinclair et al. (2019) reported assessing students' behavioral outcomes only at the end of the study by using teachers' ratings and by including a maintaining phase with three data points to monitor students' behavioral performance after the intervention. However, Fairbanks et al. (2007) and Pearce (2009) did not assess students' post-intervention behavioral outcomes to determine whether students maintained the desirable behaviors.

3.2.1 Treatment Validity and Reliability

All reviewed studies in this systematic review reported checking the validity of the intervention. Three studies reported the validity of the intervention through a quantitative index: Cheney et al. (2008) reported a validity of 96.3\% adherence of providing daily progress report (DPR) feedback, and 91.6\% for providing DPR feedback. Fairbanks et al. (2007) indicated achieving 88\% validity of implementing CICO in classroom A and 94\% in classroom B, while the validity of the intervention of the second study was reported to be $80.75 \%$ across students. McIntosh et al. (2009) stated that the validity of the intervention in their study achieved the high level of $94 \%$.

The social validity of the intervention was assessed in four studies by developing a checklist or questionnaires to evaluate the intervention by teachers (Barnett et al., 2006; Fairbanks et al., 2007; McIntosh et al., 2009; Sinclair et al., 2019; Szwed \& Bouck, 2013). In addition, Sinclair et al. (2019) and Szwed and Bouck (2013) asked participating students about the usefulness of the intervention. Pearce (2009) found that the validity of Tier I was identified by discussing the Tier I implementation with the principal and teachers, while the validity of Tiers II and III were assessed weekly through discussing the intervention implementation during a team meeting. Pearce (2009) also reported assessing the validity of parents' participation by using a parent self-report. In two of the included single-subject studies (Sinclair et al., 2019; Szwed \& Bouck, 2013), researchers added maintenance phase to observe students' maintenance of desirable behaviors within three points after the study. 
The reliability of the RtI intervention in promoting the behavioral outcomes across students with or at risk of ED was not reported in the three studies included in this systematic review (Barnett et al., 2006; McIntosh et al., 2009; Pearce, 2009). While the rest of the included studies followed different ways to evaluate the reliability of the intervention, Sinclair et al. (2019) and Szwed and Bouck (2013) determined the reliability of the intervention in their studies by identifying interobserver agreement, which was 100\% in Szwed and Bouck (2013) and 85\% in Sinclair et al. (2019). Fairbanks et al. (2007) enhanced the reliability of their study by providing operational definitions of the targeted behaviors and by developing an observation system to enhance the reliability of the observation. Cheney et al. (2008) suggested assessing the reliability of the intervention by using a checklist to assess the quality and adherence of providing the intervention.

\subsection{Independent and Dependent Variables}

3.3.1 RtI Behavioral Intervention

The review of RtI implementation in the seven included studies indicated that, although intervention components have some similarities, RtI interventions were planned and delivered in different ways to support students with or at risk of ED. For this reason, schools or researchers did not follow a unified way of applying RtI to support students with or at risk of ED. However, some of the reviewed studies did not provide information about how Tier I (Cheney et al., 2008; Sinclair et al., 2019; Szwed \& Bouck, 2013) and Tier III (Cheney et al., 2008; McIntosh et al., 2009; Sinclair et al., 2019) of RtI interventions were planned and applied to support students' behavioral outcomes.

\subsubsection{Tier I}

Four out of seven studies provided information about Tier I of RtI components that were applied to support all students' behavioral outcomes in general classrooms. All of these studies provided students with clear classroom behavioral expectations and roles as an essential prevention component of Tier I (Barnett et al., 2006; Fairbanks et al., 2007; McIntosh et al., 2009; Pearce, 2009). In addition, three studies emphasized developing a hierarchy of classroom consequences that focused on addressing negative behaviors (Fairbanks et al., 2007; Pearce, 2009) and enhancing positive behaviors (Barnett et al., 2006). Across the reviewed studies, implementation of Tier I of RtI varied in the rest of the intervention components. In Barnett et al. (2006), the intervention included teaching students class-wide roles that allowed students to practice what they had learned. Students were also provided with alternation of activities that they have high-interest in. In Pearce (2009), Tier I intervention included multiple components such as using a board system to clarify increasing levels of inappropriate behavior, applying the Character Counts! program to encourage character development in six areas (trustworthiness, respect, responsibility, fairness, caring, and citizenship), identifying students as model citizens for doing desirable behaviors, providing them with public praise and feedback, talking with the student about their inappropriate behavior, contacting parents about their children's behaviors, and removing student's privilege. In Fairbanks et al. (2007), the behavioral outcomes of students were enhanced through Tier I by using behavior respect tickets and teaching them school-wide behavioral expectations. In McIntosh et al. (2009), Tier I of RtI aimed to promote safety, respect, and responsibility across students; however, the study did not state which behavioral techniques and strategies were used to achieve the desired behavioral goals.

3.3.3 Tier II

Check-in and check-out (CICO) intervention was a frequently mentioned behavioral intervention in three of the studies that discussed implementing RtI to address behavioral challenges and promote positive behavioral outcomes among students (Cheney et al., 2008; Fairbanks et al., 2007; McIntosh et al., 2009). In Cheney et al. (2008), CICO was applied as a part of the CCE program, where coaches monitored students' behaviors and recorded them in a DPR. In two studies, students' social skills were developed through training provided as Tier II of RtI ; in one study, students learned and practiced solving social problems (Barnett et al., 2006), and in the other study the social training included coaching, skills introduction, modeling, role-playing and rehearsal, and feedback (Pearce, 2009). In addition to the CICO intervention in Fairbanks et al. (2007), students were provided with feedback about their behavior. In McIntosh et al. (2009), CICO intervention was based on the function of problem behavior, and students were given examples of acceptable and unacceptable behavior in school. In Cheney et al. (2008), the researchers confirmed that the schools included in the study applied CICO intervention as well as other behavioral techniques and strategies not discussed in the study. However, the researchers reported common components of RtI behavioral intervention between these schools, including CCE, CICO, behavior education program, and praising students when they meet the DPR's goals. Other intervention components were provided through the RtI model; for example, Sinclair et al. (2019) reported using peer-assisted learning strategies (PALS) with self-graphing of how many words-per-minute the student read correctly to address disruptive behavior and academic engagement.

Two studies applied Tier II intervention by emphasizing the implementation of some components from Tier I. For instance, Barnett et al. (2006) stated that paying positive attention to students' appropriate behaviors is a component of Tier I and II intervention. Pearce (2009) mentioned that parent involvement is a component of all 
RTI tiers. Tier II and III intervention also included the following similar components: applied behavior analysis strategies, such as reinforcement programs (token economies and differential reinforcement), time out or workaway programs, and environmental restructuring programs; social skills training, including cognitive-behavioral intervention (written and verbal problem-solving processes, self-monitoring, practicing of skills, self-directed speech, and feedback from staff and peers); differentiated instructional practices to enhance students' academic outcomes (differentiating content, process, products, using manipulatives, activity-based instruction, visual representation of material, and inquiry-based approaches); and individual and group counseling.

In Szwed and Bouck (2013), students with behavioral challenges were supported in Tier II by receiving accommodation and self-monitoring intervention, and in Tier II they were provided with behavioral expectations, which is pointed as a component of Tier I of RtI in other studies (Barnett et al., 2006; Fairbanks et al., 2007; McIntosh et al., 2009; Pearce, 2009).

3.3.4 Tier III

In the seven studies reviewed, limited information was mentioned for how students with or at risk of ED can be supported within Tier III of RtI. Four of the seven studies provided brief information about the intervention components that can be applied to enhance behavioral outcomes across students who have behavioral challenges (Barnett et al., 2006; Fairbanks et al., 2007; Pearce, 2009; Szwed \& Bouck, 2013). The components of the Tier III intervention in Barnett et al. (2006) focused on developing a safety plan for positive behavior support, providing students with social stories, and exchanging notes between the school and the home. In Fairbanks et al. (2007), Tier III concentrated on providing students who have behavioral challenges with a functional, individualized plan for behavior support. In Pearce (2009) and Szwed and Bouck (2013), Tier III components were similar to the intervention components provided by Tier II. However, the intervention of Tier III in Szwed and Bouck (2013) added to the Tier III intervention teaching positive social behavior to the target students. Pearce (2009) also pointed out that in addition to implementing Tier II intervention components in Tier III, students in Tier III were placed in a special education program and sometimes received mental health support outside the school, and/or they were placed in alternative education settings. The three remaining studies did not mention Tier III interventions (Cheney et al., 2008; McIntosh et al., 2009; Sinclair et al., 2019).

3.3.5 Dependent Variables

Studies that discussed RtI implementation to support students with or at risk of ED aimed to address different patterns of challenging behaviors. In all reviewed studies, researchers did not provide operational definitions of the behaviors targeted by the RtI interventions, so it is unclear which behaviors were targeted by each tier of RtI. Three studies provided general statements about the dependent variables and defined them as behavioral challenges or problems (Cheney et al., 2008; McIntosh et al., 2009; Pearce, 2009); two of these studies described these problems as serious behavioral problems (Cheney et al., 2008) or as significant emotional and behavioral problems (Pearce, 2009). In the third study, researchers described the dependent variables as students' results in three measures: the BASC-2, adaptive scales, and office discipline referrals (ODR) (McIntosh et al., 2009).

The rest of the studies provided a list of dependent variables. In Barnett et al. (2006), the list includes jumping off furniture, elopement, peer aggression, and noncompliance. The list of challenging behaviors in Fairbanks et al. (2007) focused on inappropriate physical contact, talk-outs, inappropriate placement, noncompliance, nondisruptive off-task behavior, and academic engagement. In Szwed and Bouck (2013), students' off-task behaviors were the main dependent variables, such as students leaving their seats, fidgeting with instructional materials (e.g., books, paper, pencils) when not required to use them, and talking disruptively. Dependent variables in Sinclair et al. (2019) included both academic and behavioral aspects: The academic aspects included the student's score in passage-reading fluency, and the behavioral aspects included the student's academic engagement and disruptive behavior, such as calling out instead of raising a hand, throwing papers, tapping a pencil on the desk, and interrupting other students.

\subsection{Implementing Screening and Progress Monitoring}

To assess students' behavioral performance within the RtI model, researchers in the included studies used a variety of tools. These tools depend on observing students in four studies: in Fairbanks et al. (2007), Sinclair et al. (2019), and Szwed and Bouck (2013), the researchers reported using a behavior interval recording system. Barnett et al. (2006) mentioned multiple ways to observe and record students' behaviors, such as using indicator reports with teacher observations linked to curriculum objectives and students' behavior, conducting classroom observations by mental health consultants, and applying narrative observations in real time. In three studies, researchers also included functional behavior assessment and interviewed teachers to collect information about students' behavioral challenges (Barnett et al., 2006; McIntosh et al., 2009; Pearce, 2009). In Barnett et al. (2006), parents and teachers were both interviewed. The information about students' behavioral challenges was also collected using ODR data (Fairbanks et al., 2007; McIntosh et al., 2009; Pearce, 2009), behavioral scales (Cheney et al., 2008; Fairbanks et al., 2007; McIntosh et al., 2009), and DPR (Cheney et al., 2008).

Although most of the included studies focused on assessing students' behavioral performances, two studies 
used tools to monitor students' progress in reading, literacy, and other academic subjects, such as passage-reading fluency (PRF), curriculum-based measurement (Sinclair et al., 2019), and early literacy screening (Barnett et al., 2006). All the reviewed studies included information about how the data were collected for students' behaviors within the RtI model; however, these studies lack information about the aims of these tools, such as how to use them to screen or monitor students' progress. These studies also lack information about how frequently the tools were used, which RtI tiers these tools were used in, what the set benchmarks were in the utilized assessment tools, and how the collected data from screening and progress monitoring were used to make decisions about students.

\subsection{RtI Implementation Outcomes}

In the reviewed studies, most students $(80 \%)$ with or at risk of ED who received RtI intervention showed positive behavioral outcomes in response to the interventions provided within the RtI tiers. All studies reported declines in disruptive behaviors among students who were targeted by RtI intervention. Two studies reported an increase in students' on-task behaviors after receiving peer-assisted learning in Tier II (Sinclair et al., 2019) and selfmonitoring in Tiers II and III (Szwed \& Bouck, 2013). McIntosh et al. (2009) reported that receiving behavioral intervention within the RtI model contributes to improving prosocial behavior and decreasing ODR. Barnett et al. (2006) suggested that RtI can be implemented at the kindergarten level to identify students with behavioral needs and provide them with appropriate supports. Pearce (2009) stated that using applied behavior analysis interventions and enhancing parental involvement through the RtI model will likely benefit students at the kindergarten and first-grade levels.

In general, although the reviewed studies indicated positive behavioral outcomes after implementing RtI among students with or at risk of ED, especially after receiving Tiers I and II of behavioral interventions, the results of the reviewed studies reported that some students did not respond to Tiers I and II. According to Pearce (2009), despite the positive outcomes recorded among students after implementing the RtI model, students in kindergarten and the first grade were less likely to benefit from social skills training and cognitive behavioral intervention. Similarly, besides reporting positive impacts of RtI intervention in students' on-task behaviors, Szwed and Bouck (2013) asserted that students did not maintain their improved on-task behavior during the withdrawal and maintenance phases after receiving self-monitoring intervention. Sinclair et al. (2019) also found no functional relationship between the intervention and the student's academic achievement in PRF when students were provided with peer-assisted learning within Tier II. Moreover, McIntosh et al. (2009) found that although students with attention-maintained behavior were significantly improved, students with escape-maintained behavior did not show significant improvement in their response to the received intervention within RtI. Indeed, the rating of their problem behavior was increased throughout the intervention.

\section{Discussion}

RtI has a long history as a pre-referral model for preventing academic failure among students and providing adequate intervention to promote academic success (Beratan, 2006). Some researchers have now suggested using RtI to provide emotional and behavioral supports to students with or at risk of ED (Hawken et al., 2008; Sugai \& Horner, 2009). The current systematic review of seven studies examined the effectiveness of implementing RtI to support students with or at risk of ED, and it found that the RtI model can be used to deliver intervention with potentially positive effects on improving students' behavioral outcomes. The results of the reviewed studies indicate that RtI holds promise for reducing destructive behaviors among students with behavioral problems (Barnett et al., 2006; Cheney et al., 2008; Fairbanks et al., 2007; McIntosh et al., 2009; Pearce, 2009) and for increasing their on-task behavior (Sinclair et al., 2019; Szwed \& Bouck, 2013).

However, although RtI implementation showed benefits for improving the behavioral performance of students with or at risk of ED, the results also indicated that some students did not respond to the behavioral interventions provided through Tier I and Tier II of RtI. Some participating students did not respond to Tiers I and II of RtI behavioral interventions. Studies that included students unresponsive to RtI behavioral instructions did not clearly explain this lack of response (Cheney et al., 2008; Fairbanks et al., 2007). Researchers did not discuss the percentage of students unresponsive to Tier II in the reviewed studies if it met $5 \%$, which is the percentage recommended in the RtI literature for unresponsive students that can be supported within Tier III of RtI (Utley \& Obiakor, 2012).

The results of some reviewed studies also highlighted issues related to students' limited behavioral outcomes after receiving behavioral intervention through RtI, such as not recording positive effects across kindergarten and first grade students when given social skills training and cognitive behavioral intervention within RtI (Pearce, 2009). In addition to this issue, McIntosh et al. (2009) didn't find improvement in students' behaviors and instead recorded an increase in students' problematic behavior during the intervention. Other issues were not maintaining behavioral improvement in the withdrawal and maintenance phases (Szwed \& Bouck, 2013), and not showing functional relationships between the intervention and the student's academic achievement (Sinclair et al., 2019).

The results of the current systematic review demonstrate that although RtI is a promising model for providing 
behavioral support to students with or at risk of ED, there is still limited empirical evidence for its implementation (Fletcher, 2019; Reynolds \& Shaywitz, 2009). The studies included in this review examined the effectiveness of implementing a single component of RtI or part of RtI implementation; this was noted by Ridgeway, Price, Simpson, and Rose (2012) after reviewing 11 studies that examine the efficacy of RtI models in promoting students' academic outcomes. Ridgeway et al. (2012) asserted that published studies in RtI efficacy examined a single component of RtI rather than studying the comprehensive process of RtI, including the implementation of whole components. The majority of studies included multiple independent and dependent variables without clarifying which variable had significant impact on the other variable.

The positive results from the reviewed studies should take into consideration that one or more experimental research procedures in these studies are missing, such as the quality indicators highlighted by the Council for Exceptional Children (2014), which include the school's setting and context (e.g., geographical region, school settings, socioeconomic status), participants (e.g., ethnicity, language proficiency, medication use, socioeconomic status), study sampling and designs (e.g., description of study design, randomization in sampling, pre- and posttest implementation, employing control and comparison condition, describing the intervention agent's role, reliability of implementation), and so on. It is important to emphasize that the reviewed studies lacked important information about RtI implementation, such as how the decision was taken regarding unresponsive students, what benchmark points guided the decision-making process (e.g., are they arbitrary or theoretical percentile of cutoffs scores), and how Tiers I and III of RtI were planned and implemented (Ogonosky, 2009; Tileston, 2011).

\subsection{Limitation}

This systematic review aims to identify the effectiveness of implementing RtI to support students with or at risk of ED. However, based on the important results found in this study, it is important to emphasize that this study has some limitations that need to be addressed in future research. First, the review did not include information related to the effect size, meta-analysis, and other factors because the reviewed studies lacked relevant information on these areas and followed inconsistent procedures when applying RtI to support students with ED. Moreover, this study did not include information about the psychometric properties of the assessment tools used to assess students' responses to the behavioral intervention, nor did it include information about whether the educators who provided the behavioral intervention within the RtI tiers had been professionally trained to do so. The results of the current review were unexpected because tiered support models such as MTSS, PBIS, and RtI generally have similar components, such as the implementation of screening, multiple tiers of intervention and prevention, progress monitoring, and evidence-based practices (Lane et al., 2019). The results reflect the need for future research to indicate what the best tiered support models are that schools can adopt to address behavioral challenges among students with or at risk of ED. Additionally, there is a need to clarify how schools that adopt a tiered support model commonly implemented to provide academic support, such as RtI, can also provide appropriate behavioral prevention and intervention support for students with or at risk of ED.

\subsection{Implications for Research and Practice}

A myriad of studies have highlighted the link between students' behavioral performance and academic outcomes (Al Otaiba \& Fuchs, 2002; Gage et al., 2015). This link emphasizes the importance of integrating behavioral and academic aspects in the intervention developed by schools to support students who have behavioral and academic needs (Gage et al., 2015; Nelson et al., 2003). Recently, some researchers have suggested integrating aspects of positive behavioral support into the RtI model to support students with or at risk of ED (Brown-Chidsey \& Steege, 2010). The results of the current systematic review indicated the positive potential effect of implementing RtI intervention to support students with or at risk of ED. However, the need for further literature is essential because only a few experimental studies have examined this topic (Sugai \& Horner, 2009). In this review, only seven experimental research studies discussed the implementation of RtI to enhance students' behavioral outcomes, and most focused on lower elementary school levels (Cheney et al., 2008; Fairbanks et al., 2007; Pearce, 2009; Szwed $\&$ Bouck, 2013). Therefore, future research should study the implementation of the RtI model in middle and high schools (Cobb, Sample, Alwell \& Johns, 2005). Researchers in the included studies followed different processes to identify and support students with behavioral challenges; therefore, future research should seek to identify consistent RtI implementation procedures to ensure that students who don't respond to the intervention are unresponsive because of issues related to them, not because of the RtI implementation (Gerber, 2005).

Research is also needed to guide educators to implement RtI components (Kovaleski, VanDerHeyden \& Shapiro, 2013) in a way appropriate to students' needs and ethnicities (Tileston, 2011). Most of the included studies focused on evaluating RtI to reduce distractive behaviors across target students who constituted a homogeneous group; however, other behavioral practices need to be discussed, such as how RtI intervention can be used to build, replace, or modify students' behaviors to enhance their behavioral and academic outcomes (Macklem, 2014). The intervention period and its effect on how students master desirable behaviors need to be considered by researchers as important variables that can impact RtI implementation outcomes (Ridgeway et al., 2012). One important 
finding that needs to be covered in future research is that about $78 \%$ of students who were identified for Tier II or III of RtI intervention were male and $22 \%$ were female. This indeed raises important questions about whether RtI intervention is planned and implemented by considering the differences of ED indicators and symptoms between male and female students (Rice \& Yen, 2010). Further research is thus needed to determine how the needs of female students with or at risk of ED can be addressed within RtI.

\section{References}

Al Otaiba, S., \& Fuchs, D. (2002). Characteristics of children who are unresponsive to early literacy intervention. Remedial and Special Education, 23, 300-316. doi:10.1177/07419325020230050501

Algozzine, B., Putnam, R., \& Horner, R. (2012). Support for teaching students with learning disabilities academic skills and social behaviors within a response-to-intervention model: Why it doesn't matter what comes first. Insights on Learning Disabilities, 9, 7-36

Barnett, D. W., Elliott, N., Wolsing, L., Bunger, C. E., Haski, H., McKissick, C., \& Vander Meer, C. D. (2006). Response to intervention for young children with extremely challenging behaviors: What it might look like. School Psychology Review, 35, 568-582. doi:10.1080/02796015.2006.12087962

Beratan, G. D. (2006). Institutionalizing inequity: Ableism, racism and IDEA 2004. Disability Studies Quarterly, 26, 3. doi:10.18061/dsq.v26i2.682

Bradley, M., Daley, T., Levin, M., O'Reilly, F., Parsad, A., Robertson, A., \& Werner, A. (2011). IDEA national assessment implementation study. Final report. NCEE 2011-4027. Washington, DC: National Center for Education Evaluation and Regional Assistance.

Brown-Chidsey, R., \& Steege, M. W. (2010). Response to intervention: Principles and strategies for effective practice. New York, NY: Guilford Press.

Bruhn, A. L., Lane, K. L., \& Hirsch, S. E. (2014). A review of tier 2 interventions conducted within multitiered models of behavioral prevention. Journal of Emotional and Behavioral Disorders, 22, 171-189. doi: $10.1177 / 1063426613476092$

Cheney, D., Flower, A., \& Templeton, T. (2008). Applying response to intervention metrics in the social domain for students at risk of developing emotional or behavioral disorders. The Journal of Special Education, 42, 108-126. doi:10.1177/0022466907313349

Cobb, B., Sample, P., Alwell, M., \& Johns, N. (2005), Effective interventions in dropout prevention: A research synthesis. The effects of cognitive-behavioral interventions on dropout for youth with disabilities. [Online] Available: https://transitionta.org/sites/default/files/graduation/NDPCSD Research Synthesis Effects of CognitiveBehavioralInterventions.pdf (October 7, 2020)

Council for Exceptional Children. (2014), Council for exceptional children standards for evidence-based practices in special education. [Online] Available: https:/www.cec.sped.org/ /media/Images/Standards/CEC\%20EBP\%20Standards\%20cover/CECs\%20Evid ence $\% 20$ Based\%20Practice\%20Standards.pdf (October 7, 2020)

Diliberti, M., Jackson, M., Correa, S., \& Padgett, Z. (2019), Crime, violence, discipline, and safety in US public schools: Findings from the school survey on crime and safety: 2017-18. First look. NCES 2019-061. [Online] Available: https://nces.ed.gov/pubs2019/2019061.pdf (November 21, 2020)

Fairbanks, S., Sugai, G., Guardino, D., \& Lathrop, M. (2007). Response to intervention: Examining classroom behavior support in second grade. Exceptional Children, 73, 288-310. doi:10.1177/001440290707300302

Fletcher, J. M. (2019), Identifying learning disabilities in the context of response to intervention: A hybrid model. [Online] Available: http://rtinetwork.org/learn/ld/identifyingld\#top (October 10, 2020)

Gage, N. A., MacSuga-Gage, A. S., Prykanowski, D., Coyne, M., \& Scott, T. M. (2015). Investigating the collateral effects of behavior management on early literacy skills. Education and Treatment of Children, 38, 523-540. doi:10.1353/etc.2015.0018

Gerber, M. M. (2005). Teachers are still the test. Journal of Learning Disabilities, 38, 516-524. doi:10.1177/00222194050380060701

Greenwood, C. R., Kratochwill, T. R., \& Clements, M. (2008). Schoolwide prevention models: Lessons learned in elementary schools. New York, NY: Guilford Press.

Gresham, F. (2015). Evidence-based social skills interventions for students at risk for EBD. Remedial and Special Education, 36, 100-104. doi:10.1177/0741932514556183

Gresham, F. M. (2007). Response to intervention and emotional and behavioral disorders. Assessment for Effective Intervention, 32, 214-222. doi:10.1177/15345084070320040301

Gresham, F. M., Hunter, K. K., Corwin, E. P., \& Fischer, A. J. (2013). Screening, assessment, treatment, and outcome evaluation of behavioral difficulties in an RTI model. Exceptionality, 21, 19-33. doi:10.1080/09362835.2013.750115

Grosche, M., \& Volpe, R. J. (2013). Response-to-intervention (RTI) as a model to facilitate inclusion for students with learning and behaviour problems. European Journal of Special Needs Education, 28, 254-269. 
doi:10.1080/08856257.2013.768452

Hawken, L. S., Vincent, C. G., \& Schumann, J. (2008). Response to intervention for social behavior. Journal of Emotional and Behavioral Disorders, 16, 213-225. doi:10.1177/1063426608316018

Hosp, J. L., Huddle, S., Ford, J. W., \& Hensley, K. (2016). Learning disabilities/special education. In: S. R. Jimerson, M. K. Burns, \& A. M. VanDerHeyden (Eds.), Handbook of response to intervention, pp. 43-58, New York, NY: Springer.

IDEA. (2004), Individuals with disabilities education act, 20 U.S.C. $\S 300.8$. Sec. 300.8 child with a disability. [Online] Available: https://sites.ed.gov/idea/regs/b/a/300.8 (October 10, 2020)

Jimerson, S. R., Burns, M. K., \& VanDerHeyden, A. M. (2016). From response to intervention to multi-tiered systems of support: Advances in the science and practice of assessment and intervention. In: S. R. Jimerson, M. K. Burns, \& A. M. VanDerHeyden (Eds.), Handbook of response to intervention, pp. 1-6, New York, NY: Springer.

Karam, D., \& Wright, J. (2015), RTI toolkit: A practical guide for schools RTI: Integrating academics and behavior. [Online] Available: http://www.interventioncentral.org/OCMBOCES (November 15, 2020)

Kauffman, J. M., \& Landrum, T. J. (2018). Characteristics of emotional and behavioral disorders of children and youth. New York, NY: Pearson.

Kovaleski, J. F., VanDerHeyden, A. M., \& Shapiro, E. S. (2013). The RTI approach to evaluating learning disabilities. New York, NY: Guilford Publications.

Lane, K. L., Oakes, W. P., Buckman, M. M., \& Menzies, H. M. (2019). Comprehensive, integrated, three-tiered (Ci3T) models of prevention: Considerations for the field. In: D. Bateman \& M. Yell (Eds.), Current trends and legal issues in special education, pp. 23-32, Thousand Oaks, CA: Corwin.

Lewis, T. J., Mitchell, B. S., Bruntmeyer, D. T., \& Sugai, G. (2016). School-wide positive behavior support and response to intervention: System similarities, distinctions, and research to date at the universal level of support. In: S. R. Jimerson, M. K. Burns, \& A. M. VanDerHeyden (Eds.), Handbook of response to intervention, pp. 703-717, New York, NY: Springer.

Liberati, A., Altman, D. G., Tetzlaff, J., Mulrow, C., Gøtzsche, P. C., Ioannidis, J. P. A., Clarke, M., Devereaux, P. J., Kleijnen, J., \& Moher, D. (2009). The PRISMA statement for reporting systematic reviews and metaanalyses of studies that evaluate health care interventions: Explanation and elaboration. PLoS Medicine, 6, e1000100. doi:10.1371/journal.pmed.1000100

Macklem, G. L. (2014). Preventive mental health at school: Evidence-based services for students. New York, NY: Springer.

Malecki, C. K., \& Demaray, M. K. (2007). Social behavior assessment and response to intervention. In: S. R. Jimerson, M. K. Burns, \& A. M. VanDerHeyden (Eds.), Handbook of response to intervention, pp. 161-171, New Nork, NY: Springer.

McIntosh, K., Bohanon, H., \& Goodman, S. (2010). Toward true integration of academic and behavior response to intervention systems. Part three: Tier 3 support. Communiqué, 39, 30-31

McIntosh, K., Campbell, A. L., Carter, D. R., \& Rossetto Dickey, C. (2009). Differential effects of a tier two behavior intervention based on function of problem behavior. Journal of Positive Behavior Interventions, 11, 82-93. doi:10.1177/1098300708319127

McIntosh, K., Goodman, S., \& Bohanon, H. (2010). Toward true integration of response to intervention systems in academic and behavior support: Part 2: Tier 2 support. Communiqué, 39, 4-6

National Center for Education Statistics. (2019), The condition of education a letter from the commissioner. [Online] Available: https://nces.ed.gov/programs/coe/indicator_cgg.asp (October 10, 2020)

Nelson, J. R., Benner, G. J., \& Gonzalez, J. (2003). Learner characteristics that influence the treatment effectiveness of early literacy interventions: A meta-analytic review. Learning Disabilities Research and Practice, 18, 255-267. doi:10.1111/1540-5826.00080

Nelson, J. R., Benner, G. J., Lane, K., \& Smith, B. W. (2004). Academic achievement of K-12 students with emotional and behavioral disorders. Exceptional Children, 71, 59-73. doi:10.1177/001440290407100104

Odom, S. L., Brantlinger, E., Gersten, R., Horner, R. H., Thompson, B., \& Harris, K. R. (2005). Research in special education: Scientific methods and evidence-based practices. Exceptional Children, 71, 137-148. doi:10.1177/001440290507100201

Office of Special Education and Rehabilitative Services. (2016), OSEP dear colleague letter on supporting behavior of students with disabilities. [Online] Available: https://www2.ed.gov/policy/gen/guid/schooldiscipline/files/dcl-on-pbis-in-ieps--08-01-2016.pdf (October 7, 2020)

Ogonosky, A. (2009). The response to intervention handbook: Moving from theory to practice. Austin, TX: Park Place Publications.

Pearce, L. R. (2009). Helping children with emotional difficulties. The Rural Educator, 30, 34-46. doi:10.35608/ruraled.v30i2.452

Reynolds, C. R., \& Shaywitz, S. E. (2009). Response to intervention: Ready or not? Or, from wait-to-fail to watch- 
them-fail. School Psychology Quarterly, 24, 130-145. doi:10.1037/a0016158

Rice, E. H., \& Yen, C. J. (2010). Examining gender and the academic achievement of students with emotional disturbance. Education and Treatment of Children, 33, 601-621. doi:10.1353/etc.2010.0011

Ridgeway, T. R., Price, D. P., Simpson, C. G., \& Rose, C. A. (2012). Reviewing the roots of response to intervention: Is there enough research to support the promise? Administrative Issues Journal, 2, 9. doi:10.5929/2011.2.1.8

Saeki, E., Jimerson, S. R., Earhart, J., Hart, S. R., Renshaw, T., Singh, R. D., \& Stewart, K. (2011). Response to intervention (RtI) in the social, emotional, and behavioral domains: Current challenges and emerging possibilities. Contemporary School Psychology, 15, 43-52

Sinclair, A. C., Gesel, S. A., \& Lemons, C. J. (2019). The effects of peer-assisted learning on disruptive behavior and academic engagement. Journal of Positive Behavior Interventions, 21, 238-248. doi:10.1177/1098300719851227

Stoutjesdijk, R., Scholte, E. M., \& Swaab, H. (2012). Special needs characteristics of children with emotional and behavioral disorders that affect inclusion in regular education. Journal of Emotional and Behavioral Disorders, 20, 92-104. doi:10.1177/1063426611421156

Sugai, G., \& Horner, R. H. (2009). Responsiveness-to-intervention and school-wide positive behavior supports: Integration of multi-tiered system approaches. Exceptionality, 17, 223-237. doi:10.1080/09362830903235375

Szwed, K., \& Bouck, E. C. (2013). Clicking away: Repurposing student response systems to lessen off-task behavior. Journal of Special Education Technology, 28, 1-12. doi:10.1177/016264341302800201

Tileston, D. W. (2011). Closing the RTI gap: Why poverty and culture counts. Indiana: Solution Tree Press.

Utley, C., \& Obiakor, F. (2012). Response to intervention and positive behavior interventions and supports: Merging models to improve academic and behavioral outcomes of culturally and linguistically diverse children with learning disabilities. Insights on Learning Disabilities, 9, 37-67

WWC. (2019), What Works Clearinghouse standards handbook, version 4.0. [Online] Available: https://ies.ed.gov/ncee/wwc/Docs/referenceresources/wwc_standards_handbook_v4.pdf (October 12, 2020)

\section{Author biography}

Areej Alsalamah is an Assistant Professor of Special Education in the Department of Special Education at King Saud University. She received her B.A. and M.S. in Special Education- Learning Disabilities from King Saud University, and her Ph.D. in Special Education with a concentration in tiered-support models from Washington State University. Areej's background and research interests include the implementation of tiered-support models and providing behavioral and academic support to students with disabilities. She can be reached by email at: aalsalama@KSU.EDU.SA.

Tables

Table 1. Summary of the included studies

\begin{tabular}{|c|c|c|c|c|c|c|}
\hline Study & Study design & Participants & Setting & RtI tier & $\begin{array}{l}\text { Dependent } \\
\text { variable(s) }\end{array}$ & Results \\
\hline $\begin{array}{l}\text { Barnett et } \\
\text { al. (2006) }\end{array}$ & $\begin{array}{l}\text { Single-case } \\
\text { design } \\
\text { Multiple- } \\
\text { treatment } \\
\text { design } \\
\text { (A-BCD-BC-B) }\end{array}$ & $\begin{array}{l}\text { (1) 4-year-old girl } \\
\text { with behavioral } \\
\text { challenges but } \\
\text { without } \\
\text { disabilities }\end{array}$ & $\begin{array}{l}\text { Kindergarten in } \\
\text { school with Head } \\
\text { Start program; } \\
\text { classroom, } \\
\text { playground, and } \\
\text { lunchroom }\end{array}$ & $\begin{array}{l}\text { Tier I } \\
\text { Tier II } \\
\text { Tier III }\end{array}$ & $\begin{array}{l}\text { Behavioral } \\
\text { challenges: } \\
\text { jumping off } \\
\text { furniture, } \\
\text { elopement, peer } \\
\text { aggression, } \\
\text { noncompliance }\end{array}$ & $\begin{array}{l}\text { RTI procedures can be } \\
\text { used to identify and } \\
\text { support kindergarten } \\
\text { students who have } \\
\text { behavioral needs. The } \\
\text { challenging behaviors of } \\
\text { the target student and peers } \\
\text { continued to decline until } \\
\text { stabilizing at } 0 \% \text {. }\end{array}$ \\
\hline
\end{tabular}




\begin{tabular}{|c|c|c|c|c|c|c|}
\hline Study & Study design & Participants & Setting & RtI tier & $\begin{array}{l}\text { Dependent } \\
\text { variable(s) }\end{array}$ & Results \\
\hline $\begin{array}{l}\text { Pearce } \\
(2009)\end{array}$ & $\begin{array}{l}\text { Mixed methods } \\
\text { *Not mentioned } \\
\text { explicitly in the } \\
\text { study }\end{array}$ & $\begin{array}{l}\text { (9) students from } \\
\text { kindergarten to } \\
\text { 5th grade, } \\
\text { comprising } 7 \\
\text { males and } 2 \\
\text { females. Students } \\
\text { identified with } \\
\text { significant } \\
\text { emotional and } \\
\text { behavioral } \\
\text { problems; } 8 \\
\text { identified with } \\
\text { disabilities (e.g., } \\
\text { learning } \\
\text { disabilities, } \\
\text { ADHD, } \\
\text { oppositional } \\
\text { defiant disorder, } \\
\text { depression, } \\
\text { reactive } \\
\text { attachment } \\
\text { disorder, tuberous } \\
\text { sclerosis, bipolar } \\
\text { disorder, Asperger } \\
\text { syndrome, seizure } \\
\text { disorder); } 7 \text { out of } \\
9 \text { students were on } \\
\text { medication. }\end{array}$ & $\begin{array}{l}\text { Two rural } \\
\text { elementary schools: } \\
\text { First school } \\
\text { provided } \\
\text { educational services } \\
\text { to students from } \\
\text { kindergarten to } 2 \text { nd } \\
\text { grade. Second } \\
\text { school provided } \\
\text { educational services } \\
\text { to students from } 3 \text { rd } \\
\text { grade to } 5 \text { th grade. }\end{array}$ & $\begin{array}{l}\text { Tier I } \\
\text { Tier II } \\
\text { Tier III }\end{array}$ & $\begin{array}{l}\text { Behavioral } \\
\text { challenges } \\
\text { *Not mentioned } \\
\text { explicitly in the } \\
\text { study }\end{array}$ & $\begin{array}{l}7 \text { out of } 9 \text { students showed } \\
\text { improved behavior in } \\
\text { response to the } \\
\text { interventions within the } \\
\text { RTI tiers; } 2 \text { students did } \\
\text { not respond to intervention } \\
\text { and showed no } \\
\text { fundamental improvement } \\
\text { over the } 2 \text { years of support } \\
\text { within the RTI framework. } \\
\text { Students in kindergarten } \\
\text { and } 1 \text { st grade were less } \\
\text { likely to benefit from } \\
\text { social skills training and } \\
\text { cognitive behavioral } \\
\text { intervention, but more } \\
\text { likely to benefit from } \\
\text { applied behavior analysis } \\
\text { interventions and parental } \\
\text { involvement. }\end{array}$ \\
\hline $\begin{array}{l}\text { Cheney } \\
\text { et al. } \\
(2008)\end{array}$ & $\begin{array}{l}\text { Experimental } \\
\text { design } \\
\text { *Not mentioned } \\
\text { explicitly in the } \\
\text { study }\end{array}$ & $\begin{array}{l}\text { (127) out of } 326 \\
\text { students from } 1 \mathrm{st} \\
\text { to } 3 \text { rd grades and } \\
\text { with serious } \\
\text { behavioral } \\
\text { problems; } 100 \\
\text { male students and } \\
27 \text { female } \\
\text { students; } 23 \\
\text { students belonged } \\
\text { to different } \\
\text { disability } \\
\text { categories (e.g., } \\
\text { EBD, health } \\
\text { impairment, } \\
\text { speech language } \\
\text { impairment, } \\
\text { autism, specific } \\
\text { learning } \\
\text { disability). }\end{array}$ & $\begin{array}{l}\text { Elementary schools: } \\
\text { Schools included } \\
\text { randomly in Check, } \\
\text { Connect, and Expect } \\
\text { project; } 9 \text { schools } \\
\text { selected for } \\
\text { intervention; } 9 \\
\text { schools selected for } \\
\text { comparison. } \\
\text { Classroom, } \\
\text { playground, and } \\
\text { cafeteria }\end{array}$ & Tier II & $\begin{array}{l}\text { Behavioral } \\
\text { challenges } \\
\text { *Not mentioned } \\
\text { explicitly in the } \\
\text { study } \\
\text { Percentage of } \\
\text { points on DPR } \\
\text { Students' } \\
\text { outcomes in } \\
\text { Gresham's five } \\
\text { metrics }\end{array}$ & $\begin{array}{l}\text { The most useful Gresham } \\
\text { metrics for evaluating } \\
\text { students' progress within } \\
\text { RtI are effect size and } \\
\text { percentage of change. } 88 \\
\text { out of } 127 \text { students ( } 69 \%) \\
\text { in primary intervention } \\
\text { showed positive behavioral } \\
\text { changes; } 39 \text { students ( } 31 \%) \\
\text { in primary intervention did } \\
\text { not respond to the } \\
\text { intervention; } 62 \text { out of } 93 \\
\text { students ( } 67 \% \text { ) in } \\
\text { secondary intervention } \\
\text { showed positive behavioral } \\
\text { changes; } 31 \text { students ( } 33 \%) \\
\text { in secondary intervention } \\
\text { did not respond to the } \\
\text { intervention; } 7 \text { of them } \\
\text { were already receiving } \\
\text { special education services. } \\
\text { During the intervention, } 5 \\
\text { of the students were } \\
\text { identified for special } \\
\text { education. }\end{array}$ \\
\hline
\end{tabular}




\begin{tabular}{|c|c|c|c|c|c|c|}
\hline Study & Study design & Participants & Setting & RtI tier & $\begin{array}{l}\text { Dependent } \\
\text { variable(s) }\end{array}$ & Results \\
\hline $\begin{array}{l}\text { Fairbanks } \\
\text { et al. } \\
(2007)\end{array}$ & $\begin{array}{l}\text { Two studies. } \\
\text { First study: } \\
\text { descriptive } \\
\text { quasi- } \\
\text { experimental } \\
\text { Second study: } \\
\text { single-subject } \\
\text { A multiple } \\
\text { baseline design } \\
\text { across four } \\
\text { students }\end{array}$ & $\begin{array}{l}\text { First study: (10) } \\
\text { 2nd grade } \\
\text { students; } 7 \text { to } 8 \\
\text { years old; } 5 \text { males } \\
\text { and } 5 \text { females; } 2 \\
\text { students had } \\
\text { learning } \\
\text { disabilities. All } \\
\text { students showed } \\
\text { behavioral } \\
\text { problems and } \\
\text { were unresponsive } \\
\text { to class } \\
\text { management } \\
\text { practices. } \\
\text { Second study: (4) } \\
\text { students selected } \\
\text { from first study } \\
\text { because they did } \\
\text { not respond to the } \\
\text { intervention. All } \\
\text { of these students } \\
\text { belonged to } \\
\text { classroom B; } 2 \\
\text { students were on } \\
\text { medication. }\end{array}$ & $\begin{array}{l}\text { Suburban } \\
\text { elementary school, } \\
\text { general classroom } \\
\text { setting. Students } \\
\text { divided into } 2 \\
\text { classrooms: } \\
\text { classroom A } \\
\text { included } 3 \text { students, } \\
\text { and classroom B } \\
\text { included } 7 \text { students. }\end{array}$ & $\begin{array}{l}\text { Tier I } \\
\text { Tier II } \\
\text { Tier III }\end{array}$ & $\begin{array}{l}\text { Behavioral } \\
\text { challenges, } \\
\text { inappropriate } \\
\text { physical } \\
\text { contact, talk- } \\
\text { outs, } \\
\text { inappropriate } \\
\text { placement, } \\
\text { noncompliance, } \\
\text { nondisruptive } \\
\text { off-task } \\
\text { behavior, } \\
\text { academic } \\
\text { engagement }\end{array}$ & $\begin{array}{l}\text { Students in general showed } \\
\text { improvement in their } \\
\text { behaviors in response to } \\
\text { the intervention; } 4 \text { students } \\
\text { were unresponsive to Tier } \\
\text { II intervention and were } \\
\text { then targeted for Tier III } \\
\text { intervention, which was } \\
\text { effective in improving } \\
\text { students' behaviors. }\end{array}$ \\
\hline $\begin{array}{l}\text { Szwed } \\
\text { and } \\
\text { Bouck } \\
(2013)\end{array}$ & $\begin{array}{l}\text { A single-subject } \\
\text { withdrawal } \\
\text { design } \\
\text { (ABAB) }\end{array}$ & $\begin{array}{l}\text { (3) } 2 \text { nd grade } \\
\text { students: } 1 \text { student } \\
\text { was } 8 \text { years old } \\
\text { and was repeating } \\
2 \text { nd grade; } 2 \\
\text { students were } 7 \\
\text { years old. All } \\
\text { participants were } \\
\text { males. } 2 \text { students } \\
\text { identified with } \\
\text { ADHD; } 1 \text { was on } \\
\text { medication. } 1 \\
\text { student identified } \\
\text { with ED; he was } \\
\text { receiving special } \\
\text { education service. } \\
2 \text { students } \\
\text { excelled in math. }\end{array}$ & $\begin{array}{l}\text { Urban elementary } \\
\text { school; 2nd grade } \\
\text { included general } \\
\text { education } \\
\text { classroom; math } \\
\text { class; schools } \\
\text { provide high-ability } \\
\text { program for gifted } \\
\text { and talented } \\
\text { students. }\end{array}$ & $\begin{array}{l}\text { Tier II } \\
\text { Tier III }\end{array}$ & $\begin{array}{l}\text { Students' off- } \\
\text { task behaviors, } \\
\text { including } \\
\text { getting out of } \\
\text { their seats, } \\
\text { fidgeting with } \\
\text { instructional } \\
\text { materials (e.g., } \\
\text { books, paper, } \\
\text { pencils) when } \\
\text { not required to } \\
\text { use them, } \\
\text { disruptive } \\
\text { talking. }\end{array}$ & $\begin{array}{l}\text { Students' off-task } \\
\text { behaviors decreased during } \\
\text { the self-monitoring } \\
\text { intervention phases. } \\
\text { Students did not maintain } \\
\text { the improvement in their } \\
\text { on-task behavior during } \\
\text { withdrawal and } \\
\text { maintenance phases. }\end{array}$ \\
\hline $\begin{array}{l}\text { McIntosh } \\
\text { et al. } \\
(2009)\end{array}$ & $\begin{array}{l}\text { Quasi- } \\
\text { experimental } \\
\text { design }\end{array}$ & $\begin{array}{l}\text { (34) out of } 40 \\
\text { elementary school } \\
\text { students; from } 1 \mathrm{st} \\
\text { to } 5 \text { th grade and } 6 \\
\text { to } 11 \text { years old; } 28 \\
\text { males and } 6 \\
\text { females. Students } \\
\text { did not respond to } \\
\text { Tier I of RtI } \\
\text { behavioral } \\
\text { support. No } \\
\text { information } \\
\text { mentioned about } \\
\text { whether students } \\
\text { identified with a } \\
\text { disability. }\end{array}$ & $\begin{array}{l}6 \text { public elementary } \\
\text { schools and general } \\
\text { classroom setting }\end{array}$ & $\begin{array}{l}\text { Tier I } \\
\text { Tier II } \\
\text { *No } \\
\text { detaile } \\
\mathrm{d} \\
\text { inform } \\
\text { ation } \\
\text { about } \\
\text { Tier I } \\
\text { and III } \\
\text { interve } \\
\text { ntions. }\end{array}$ & $\begin{array}{l}\text { Problem } \\
\text { behavior based } \\
\text { on students' } \\
\text { assessments in } \\
\text { BASC-2, } \\
\text { adaptive scales, } \\
\text { and office } \\
\text { discipline } \\
\text { referrals. }\end{array}$ & $\begin{array}{l}\text { The behavior ratings of } \\
\text { students with attention- } \\
\text { maintained behavior was } \\
\text { significantly improved in } \\
\text { problem behavior, } \\
\text { prosocial behavior, and } \\
\text { office discipline referrals, } \\
\text { whereas there was no } \\
\text { significant improvement in } \\
\text { behavior among students } \\
\text { with escape-maintained } \\
\text { behavior. Indeed, the rating } \\
\text { of their problem behavior } \\
\text { increased throughout the } \\
\text { intervention. }\end{array}$ \\
\hline $\begin{array}{l}\text { Sinclair } \\
\text { et al. } \\
(2019)\end{array}$ & $\begin{array}{l}\text { A single-subject } \\
\text { withdrawal } \\
\text { design } \\
\text { (ABAB) }\end{array}$ & $\begin{array}{l}\text { (1) male 8th grade } \\
\text { student without } \\
\text { disabilities. He } \\
\text { showed frequent } \\
\text { disruptive } \\
\text { behavior and had } \\
\text { a low reading } \\
\text { level. }\end{array}$ & $\begin{array}{l}\text { Urban middle } \\
\text { schools and } \\
\text { intervention } \\
\text { classroom setting }\end{array}$ & $\begin{array}{l}\text { Tier II } \\
* \text { No } \\
\text { inform } \\
\text { ation } \\
\text { about } \\
\text { Tier I } \\
\text { or Tier } \\
\text { III. }\end{array}$ & $\begin{array}{l}\text { Disruptive } \\
\text { behavior (e.g., } \\
\text { calling out } \\
\text { instead of } \\
\text { raising hand, } \\
\text { throwing } \\
\text { papers, tapping } \\
\text { pencil on desk, } \\
\text { interrupting } \\
\text { other students); } \\
\text { academic } \\
\text { engagement }\end{array}$ & $\begin{array}{l}\text { A functional relationship } \\
\text { was found between } \\
\text { intervention and reduced } \\
\text { disruptive behavior, and } \\
\text { between intervention and } \\
\text { increased academic } \\
\text { engagement among } \\
\text { students. No functional } \\
\text { relationship was found } \\
\text { between the intervention } \\
\text { and student achievement in } \\
\text { PRF. }\end{array}$ \\
\hline
\end{tabular}

